\title{
AFRICAN HEARTLAND GEOPOLITICS OF THE FUTURE IN THE SUB-SAHARAN REGION
}

\author{
Luca DIACONESCU * \\ University of Craiova, Doctoral School of Sciences, Field of Geography, 13st, Alexandru Ioan Cuza \\ St., 200585, Craiova, Romania, e-mail: diaconesculuca@yahoo.ro
}

\section{Loredana DRAGOMIR}

University of Craiova, Doctoral School of Sciences, Field of Geography, 13st, Alexandru Ioan Cuza St., 200585, Craiova, Romania, e-mail: loredana.dragomir25@yahoo.com

Citation: Diaconescu, L., \& Dragomir, L. (2020). African Heartland Geopolitics of the Future in the Sub-Saharan Region. Revista Română de Geografie Politică, 23(1), 1-9. https://doi.org/10.30892/rrgp.231101-342

\begin{abstract}
Sub-Saharan Africa is still considered a land semi-isolated from the rest of the world, without many natural harbors or navigable rivers, or inland islands and seas, with 16 states that do not have access to the sea and D.R. Congo with limited access that is difficult to achieve. All these states that can be considered the Heartland of Africa, have now reached a total population exceeding the US population, will exceed the population of continent Europe by 2050 and will have a population similar to the continents of America and Europe taken together by 2100 .
\end{abstract}

Key words: no access to the ocean, isolated, interdependence, regionalization, population explosion

\section{INTRODUCTION}

North or Mediterranean Africa is an open world, with a white, Roman and Christian population at first and later Islamized and Arabized, close to Europe and the Middle East and inclined to trade since ancient times.

South of it, beneath the Sahara desert, a separate world lived in isolation, with its own empires but few economic and cultural ties to the north. Now, this part of the world is overpopulated under the burden of borders drawn during colonialism and which left 16 states without access to the sea (and D.R. Congo with a very limited exit), but with a growing population, forcing the 49 states each counts in total Sub-Saharan Africa, to attach driven by circumstances. These states isolated by sea routes have an area similar to all other states in the world without access to the sea, but with a population $50 \%$ more numerous and in an explosive population growth. 
Luca DIACONESCU, Loredana DRAGOMIR

This will probably be the main element of Africa's geopolitics that will make it different from the rest of the continents, becoming the surest reason for analysis with increasing interest. However, in addition to the large number of landlocked states experiencing an uncontrollable population explosion, the first geo-demographic elements that will shape African geopolitics will include the influence of foreign states, such as the European Union, the United States and the United Kingdom, China, maybe India, Russia or Brazil but also Islamist states, mainly northern Arabs, with the third predominant geopolitical element being the regionalization of sub-Saharan Africa, focusing on cultural, demographic, spiritual or material.

Through these trajectories on which the cultural region of Sub-Saharan Africa (also called Black Africa) was launched, the tendency is to resemble in relation to Europe, being spread by isolated states of seas and oceans similar to Central Europe, but extended territorially and demographically to dimensions equivalent to the southern half of Asia, copying the model of the Heartland and the Rimland, on a slightly smaller territory, much more isolated but almost as populated (Sawandji, 2018; Meinig, 1956; Ferrara, 2017).

\section{DEMOGRAPHY AND ISOLATIONISM}

Sub-Saharan African states have an area of 24 million $\mathrm{km}^{2}$, with a total of 49 states, of which 16 are without access to the sea, representing a third of the total area (Kaplan, 2015; Guillermo, 2015; Hugon, 2015).

The region is in a population explosion clearly superior to other continents worldwide, representing only $5 \%$ of the world's population in 1900, 13\% in 2020 and will increase to 38\% in 2100 (Diaconescu et al., 2019; Lopes, 2006). From just 80 million in 1900 (continental Europe 430, America 150, Asia 950), it has grown almost 15 times to 1,160 million today (while in Europe it has almost doubled to 0.7 times and reached 700 million, America has increased 6 times to 950 million and Asia has grown almost 4 times to 4,600 million).

Sub-Saharan Africa is expected to grow by another 3.5 billion by 2100 , reaching a population of between 3.9 and 4.8 billion (Europe will have between 0.6 and 0.7 billion, America 1.1-1.3 billion and Asia 4.2-5.3 billion). During this time, the population of the 16 landlocked states plus D.R. Congo has grown from just 26 million in 1900 (52 million for landlocked countries worldwide, excluding African states) to 428 million today, more than 16 times (245 million for other countries have increased only 5 times) and will reach 862 million in 2050 (306 million for the other states) and between 1,400 and over 2,000 million in 2100 (between 280 and 401 million inhabitants for countries outside Africa). Thus the population of landlocked states in the African Heartland was only half of the population of other landlocked states in 1900 , reaching a population almost twice as large and probably four to six times more numerous in the year 2100 .

Compared to the continent's population, the African Heartland had less than $17 \%$ of America's population and only $6 \%$ of Europe's population in 1900, growing to a larger population than the United States and the Philippines today, reaching $41 \%$ of America's population and $58 \%$ of Europe's population. Also over 30 years is expected to have $71 \%$ of the population of the entire continent of America and $120 \%$ of the population of the entire continent of Europe, and by 2100 will be between $117 \%$ and $156 \%$ of the population of America and between $236 \%$ and $293 \%$ of Europe's population. 


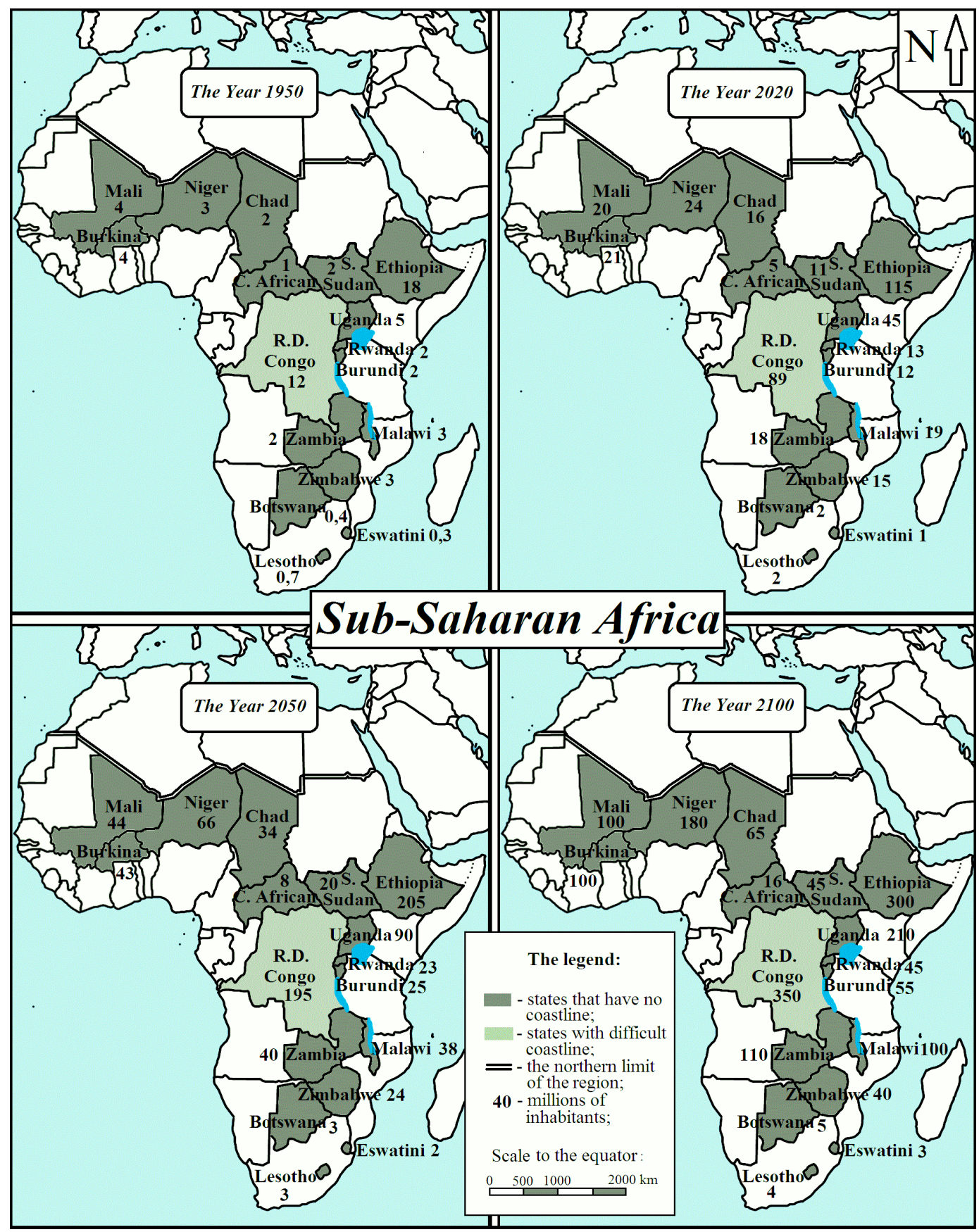

Figure 1. The evolution of the population of African states without access to the planet's ocean, between 1950 and estimated until 2100

Source: data processed after: Neguț, 2011; Diaconescu, 2017; Maesto, 2019; Worldometers, 2020

In other words, to understand the magnitude of this demographic phenomenon with atrocious geopolitical consequences, if in 1900 the report was of a resident of the current African states without access to the sea plus D.R. 
Congo to 23 inhabitants of the continents of Europe and America, so far the ratio has decreased to one African inhabitant to 4 American and European inhabitants, and by 2100 the ratio will be 1 to 1 . These African states so isolated already have a demographics as much as the entire population of states such as: Russia, Japan and Brazil taken together or as much as the entire European Union (excluding the United Kingdom).

All these changes give a development model within internal relations similar to Europe and Central Asia but much more extensive and a demographic potential similar to the Asian continent. Also, the states of the eastern half of sub-Saharan Africa already use the territory of the states of the western half for access to the Atlantic Ocean through which trade with Europe and America takes place, and conversely, the states of the eastern half represent the gateway to trade with Asia, there is a globalization at the local level such as United Europe (Mazilu, 2008; Diaconescu, 2018). This will force an African interdependence and an opening of borders most likely similar to the states that currently form the European Union, but with a population 3-4 times larger, creating the African civilizational economic boom, a concept difficult to predict at the level of 1900 when Sub-Saharan Africa was only a colony of European powers and considered in some places a possible part of Western civilization, providing for the replacement of the black population, unrepresentative, with the white population that was ten times more numerous worldwide.

The landlocked African states together have a similar area: the USA, China or mainland Europe. To give us an idea of the future situation of these states without access to the sea, we have at hand the current geopolitical relations in the land mass between Germany and Switzerland in the west and Mongolia in the east, a land that stretches over about 20 million $\mathrm{km}^{2}$ known to geopoliticians as Heartland. The continental powers and economies of this perimeter prove a tiring interdependence, forcing states to depend on each other until they reach ocean waters, routes that are paved by straits most often led by rival states, or access to icy seas.

With quite a few exceptions, many of the states of this land mass have some access to the seas and oceans. The Mediterranean Sea, the Black Sea, the Baltic Sea or the Persian Gulf are inland seas from which you exit to the Planetary Ocean only through straits and canals. In addition, the North Sea or the Arctic Ocean can be considered semi-isolated, and the frost that affects shipping a few months a year is another risk factor that accentuates the isolationist character. All the great powers or newly developed economies that with access to these seas, have always fought or strategies to facilitate their access to the Planetary Ocean, but still remained continental powers: Germany, Italy, Poland, Ukraine, Turkey, Finland, Iraq or Russia. The few states left without access at all to these seas and bays, are often crossed by navigable rivers such as: Hungary, Slovakia, Serbia or Austria crossed by Danube, Czech Republic of Elba, Belarus of the Dnieper, Switzerland of the Rhine or the Central Asian states with access to the Caspian Lake, but it also has the possibility of naval transport through the Volga River and its connections through canals that connect it to the Black Sea, the White Sea and the Gulf of Finland. Only a few exceptions, such as: Macedonia, Kosovo, Armenia, Uzbekistan, Afghanistan, Kyrgyzstan, Tajikistan or Mongolia, which have a population of less than 100 million, have no access to any sea or navigable river, so the 600 millions of Heartlanders feel less of this inconvenience, but stil that's how politics has guided them over the centuries, making them continental economies. Even in this picture of bearable isolation, it is still considered the world's largest geopolitical prison. But 
the states of Africa without access to the sea are restricted to only 11 million $\mathrm{km}^{2}$, without being crossed by navigable rivers with access to the Planetary Ocean, this African Heartland being downright severe, and can be considered to have already overcome the pole of global isolationism of the Eurasian Heartland.

Table 1. States without access to the sea. Area and population

between the years 1900 and 2100 on various categories

Source: data processed after: Marin and Marin, 2008; Neguț, 2011; Mâșu, 2014; Worldometers, 2020

\begin{tabular}{|c|c|c|c|c|c|}
\hline No. & Country & $\begin{array}{l}\text { Area } \\
\mathbf{k m}^{2}\end{array}$ & $\begin{array}{c}\text { Population } \\
1900 \\
1950 \\
\text { (millions of } \\
\text { inhabitants) }\end{array}$ & 2020 & $\begin{array}{c}\text { Estimated } \\
\text { years: } \\
2050 \\
2100\end{array}$ \\
\hline 1 & Mali & 1.240 .000 & $\begin{array}{l}1 \\
4\end{array}$ & 20 & $\begin{array}{c}44 \\
80-130\end{array}$ \\
\hline 2 & Burkina Faso & 274.000 & $\begin{array}{l}1 \\
4 \\
\end{array}$ & 21 & $\begin{array}{c}43 \\
80-130 \\
\end{array}$ \\
\hline 3 & Niger & 1.267 .000 & $\begin{array}{l}1 \\
3 \\
\end{array}$ & 24 & $\begin{array}{c}66 \\
140-210 \\
\end{array}$ \\
\hline 4 & Chad & 1.284 .000 & $\begin{array}{l}1 \\
2 \\
\end{array}$ & 16 & $\begin{array}{c}34 \\
50-80 \\
\end{array}$ \\
\hline 5 & Central African Republic & 622.000 & $\begin{array}{c}0,3 \\
1\end{array}$ & 5 & $\begin{array}{c}8 \\
13-20\end{array}$ \\
\hline 6 & South Sudanul & 619.000 & $\begin{array}{c}0,5 \\
2\end{array}$ & 11 & $\begin{array}{c}20 \\
40-50\end{array}$ \\
\hline 7 & Ethiopia & 1.127 .000 & $\begin{array}{c}5 \\
18 \\
\end{array}$ & 115 & $\begin{array}{c}205 \\
260-360 \\
\end{array}$ \\
\hline 8 & Uganda & 236.000 & $\begin{array}{l}2 \\
5 \\
\end{array}$ & 45 & $\begin{array}{c}90 \\
170-250\end{array}$ \\
\hline 9 & Rwanda & 26.000 & $\begin{array}{l}1 \\
2\end{array}$ & 13 & $\begin{array}{c}23 \\
40-50\end{array}$ \\
\hline 10 & Burundi & 27.000 & $\begin{array}{l}1 \\
2\end{array}$ & 12 & $\begin{array}{c}25 \\
45-65 \\
\end{array}$ \\
\hline 11 & Zambia & 752.000 & $\begin{array}{l}1 \\
2\end{array}$ & 18 & $\begin{array}{c}40 \\
80-130\end{array}$ \\
\hline 12 & Malawi & 118.000 & $\begin{array}{l}1 \\
3 \\
\end{array}$ & 19 & $\begin{array}{c}38 \\
80-120 \\
\end{array}$ \\
\hline 13 & Zimbabwe & 390.000 & $\begin{array}{l}1 \\
3\end{array}$ & 15 & $\begin{array}{c}24 \\
32-45\end{array}$ \\
\hline 14 & Botswana & 600.000 & $\begin{array}{l}0,1 \\
0,4 \\
\end{array}$ & 2 & $\begin{array}{c}3 \\
4-6 \\
\end{array}$ \\
\hline 15 & Lesotho & 30.000 & $\begin{array}{l}0,2 \\
0,7 \\
\end{array}$ & 2 & $\begin{array}{c}3 \\
3-4 \\
\end{array}$ \\
\hline 16 & Eswatini (Swaziland) & 17.000 & $\begin{array}{l}0,1 \\
0,3 \\
\end{array}$ & 1 & $\begin{array}{c}2 \\
2-3 \\
\end{array}$ \\
\hline- & Total & 8.630 .000 & $\begin{array}{l}17 \\
52 \\
\end{array}$ & 339 & $\begin{array}{c}668 \\
1.119-1.653 \\
\end{array}$ \\
\hline 17 & D.R. Congo & 2.345 .000 & $\begin{array}{c}9 \\
12 \\
\end{array}$ & 89 & $\begin{array}{c}195 \\
300-400 \\
\end{array}$ \\
\hline- & Total + R.D. Congo & 10.975 .000 & $\begin{array}{l}26 \\
64\end{array}$ & 428 & $\begin{array}{c}863 \\
1.419- \\
2.053 \\
\end{array}$ \\
\hline & Continent Europe & 10.180 .000 & $\begin{array}{l}430 \\
550 \\
\end{array}$ & 740 & $\begin{array}{c}720 \\
600-700 \\
\end{array}$ \\
\hline & Continent America & 42.550.000 & $\begin{array}{l}150 \\
340\end{array}$ & 1.030 & $\begin{array}{c}1.215 \\
1.100- \\
1.300\end{array}$ \\
\hline & $\begin{array}{l}\text { World countries without access to seas } \\
\text { and oceans (except African countries): } \\
\text { Bolivia, Paraguay, Czech Republic, } \\
\text { Slovakia, Hungary, Serbia, Macedonia, } \\
\text { Belarus, Armenia, Austria, Switzerland, } \\
\text { Moldova, Azerbaijan, Afghanistan, Nepal, } \\
\text { Laos, Kazakhstan, Uzbekistan, } \\
\text { Turkmenistan, Tajikistan, Kyrgyzstan, } \\
\text { Mongolia, Bhutan and so on. }\end{array}$ & 8.950 .000 & $\begin{array}{c}52 \\
100\end{array}$ & 245 & $\begin{array}{c}306 \\
280-401\end{array}$ \\
\hline
\end{tabular}


The lack of importance of the subject in the past was given by three main factors: African states being poor in recent centuries, now starting to rise economically; they were part of the colonies of European powers being united by continuous territories to the ocean; the population of these states in the past centuries has been downright negligible. But now that the economy is growing by $3 \%$ a year, after the colonial withdrawal 16 states have been completely deprived of naval access to the oceans and their population has risen to a number similar to the current population of the US and Germany together, it becomes a topic geopolitics that will rise as each decade passes (Marshall, 2019; Melinescu, 2018; Huntington, 2018; Woddis, 1965).

This change, which will last throughout the 21 st century, proves the desperation of the African Heartland states to establish friendly relations with the African Rimland, des-isolating the hundreds of millions of its inhabitants who do not have access to the cheapest and most extensive way of trade. All this population of almost one billion inhabitants in 2050 and two billion in 2100 being blocked to the north by the growing Sahara desert, and to the south by the Kalahari desert, while the African Rimland which will in turn enter a space crisis, will reach 1.5 billion people in 2050 and will probably have 2.7 billion by 2100 , being unable to manage its own territory.

In addition to these shortcomings, other states experience conflicts within them, between the coast and the interior of the country, such as: Angola, Nigeria (Northern Nigeria), Kenya, Tanzania (Zanzibar and the Islamized coast), Sudan (Darfur), D.R. Congo (Katanga), thus the number of states without access to the sea could increase reaching another 300-600 million Africans to be trapped inside isolated states (Favari, 2014; Roberts, 2009). It is difficult to even imagine that today the population of a state like the USA will live in states without access to the sea, but let's think in 2050 that all of Europe or in 2100 all of China or India or the continents of Europe and America together to be just states without access to the sea.

\section{REGIONALIZATION NUCLEI}

Africa is most often divided into two separate cultural and relational regions, one consisting of two southern thirds known as Sub-Saharan Africa and one located north of the vast mass of Saharan desert (as large as Europe, China or the USA) composed of Egypt and the Maghreb, isolated from the south, which was always involved in the cultural, economic and imperial life of the Mediterranean and the Middle and Near East, being in turn empires with their own status as the Phoenicians (Carthage) and the Egyptians, then part of the Christian Roman Empire, to be part of the Arab and Ottoman Empire that Islamized and Arabized them, after their fragmentation into European colonies, and now being culturally influenced by their membership in various Arab or Islamist structures and economically influenced by the European Union, characterizing through tourism, hydrocarbon exports and with a cessation of the population explosion since the period 2000-2010, being entirely a distinct region and total different from the south of the continent, also having the optical difference of being populated by the white race.

The southern part occupying two thirds of the continent is divided into no less than 49 states, generally artificial and not respecting the boundaries of ethnicities, tribes or religions, with borders drawn by agreements signed in the capitals of European empires such as: Paris, London, Lisbon, Berlin or Rome 
(Bessis, 2004; Nguyen, 2017; Herman and Grama, 2018). Currently, the various world powers are trying to take over part of the influence of this region, for the division of Africa into spheres of influence fighting: EU, USA, Brazil, China, Russia, India or Saudi Arabia (Favari, 2014; Carmody, 2013). Except for the current external influence, sub-Saharan Africa could be divided into four nuclei, with a rather different perception of the world and history, which gathers around them all the other countries in this part of the world. The special history makes the 4 regions to reject each other, being one of the obstacles for the creation of a unionist structure at continental level. Although there are some common elements such as the population that is distinguished by the trait of the Negro race, the region being wetter, generally dominated by jungles and savannas, except Ethiopia all were European colonies, little urbanized, little developed due to colonization in the seventeenth and nineteenth centuries, but in a demographic explosion that gives hope to become, not too many decades later, the economic-demographic copy of today's Asia in the world, but on a much more compact territory, rather related to land routes to the detriment of river routes and even maritime.

The 4 distinct Africans could be defined as follows:

- Demographic or Nigerian Africa plus the New African World (Congo);

- West-globalized or southern Africa;

- Spiritual or Ethiopian (and Nubian) Africa;

- Insular or Asian Africa.

Demographic Africa has, together with the states in its sphere of influence, almost half of the population of Sub-Saharan Africa. This is the main territory that provided slaves for plantations in America and is still economically linked to Europe and the United States. Among the dominant landscapes is the strip of the coast of Guinea between Senegal and Cameroon, an old agricultural and fishing area, well urbanized and developed compared to the rest of Africa, being attached to European values and still having the majority Christian religion. To the north of this is the Sahel, between the modernized coast and the Sahara desert, a conflict zone of contact between Christianity and Islam, with a growing water deficit and which is likely to be the region of famine and emigration center in future, here being some of the largest African empires until the arrival of the Europeans (Mali Empire, Songhai, Bornu). To the southeast is the Congo River Basin, which represents the African jungle and is beginning to easily anthropize, being a kind of New World in Africa, where the main occupations are the exploitation of raw materials, starting with a slight inclination towards plantations and culture of exotic plants, being an increasingly Christianized region. Civilized and globalized Africa is located in the south of the continent, here there are states with a high standard of living and more and more modern cities, where the exploitation of raw materials but also fishing, tourism or agriculture rise in some places to Western standards, Christianized early and which revolves around the state of South Africa. These are for Africa a kind of Argentina, Uruguay and Chile for South America, or what Japan represented for Asia in the past centuries, and the discoveries of copper, lead, zinc, etc. from Zambia and oil from Angola expand further and further north this territory, being able to include in the future the province of Katanga in D.R. Congo.

Spiritual Africa represents the remnants of the Nile Valley civilization that stretched from Egypt, passed through Nubia, and reached the sources of the Blue Nile where Abyssinia (Ethiopia) was located. With the advance of the Arab Empire in the north, Egypt and Nubia (now Sudan) were Islamized and Arabized, pushing 
the African sacred civilization further and further south, which now stretches from Ethiopia to Kenya and further into Tanzania and Malawi. Savannah area, with almost sufficient rainfall, this Christian region inside the continent (Orthodox in Ethiopia) and slightly Islamized on the coast (Eritrea, Somalia, Zanzibar) has always been in a struggle to drive away invading civilizations, stopping Islamization here Africa and Ethiopia is the only state on this continent that has not been colonized by Europeans. Increasingly developed and with larger and more modern cities, it flirts with the economic extension of East, Southeast and South Asia, being in counterweight with most of Africa that has accepted Arabization, Europeanization and Americanization. Non-African or Asian Africa, Madagascar is an island that seems to have been brought by the waves of the Indian Ocean near the Malaysian archipelago with which it shares the same type of landscape and the same race of people, its inhabitants having descendants of immigrants who came here for millennia from present Indonesia and Malaysia (Gâștescu and Cioacă, 2013).

Looking at these differences, it is clear to us why the giant of Africa (Nigeria) will not be led by sqiritual Africa (Ethiopia), West Africa (South Africa) or Asian Africa (Madagascar), the four regions with centers in: Lagos, Johannesburg, Addis Ababa and Antananarivo rejecting each other.

\section{CONCLUSIONS}

The world's major economic powers are generally open to foreign trade, which is $90 \%$ dominated by sea and river routes. There are few countries in the world that have managed to develop without access to the Planetary Ocean, including: Switzerland, Luxembourg, Austria, the Czech Republic, Hungary or Kazakhstan, but their population is small and they often have access to navigable river routes or are close to the coast. For the great demographic powers, the limited or extended access to the coast gave them the economic, maritime or continental character. Russia, China or Germany with access to the inland or frozen seas have become continental powers, having serious problems in their foreign trade, and the struggle to own land corridors or archipelago with unhindered access to the Planetary Ocean has defined their foreign policy throughout history. Instead: Japan, the United Kingdom, Spain, Portugal, the USA or Indonesia enjoy free shipping routes that have defined them as maritime powers.

Although Africa has 33 continental states with access to seas and oceans, they still behaved similarly to states with access to inland seas such as: Finland, Poland, Ukraine, Turkey, Saudi Arabia, Iraq, Venezuela and so on, due to the lack of navigable rivers that carry ships inside the continent as well as due to the lack of natural ports. But in addition to these states that resemble the Eurasian Rimland, being increasingly populated countries and in a fierce space crisis, there are also 16 states with no access to the ocean at all and D.R. Congo with reduced access, a number that could increase by the appearance other states such as: Darfur, Northern Nigeria, Katanga and so on.

These 17 states will have a population of both mainland Europe and Russia together by 2050, some being densely populated (Malawi, Rwanda, Burundi, Uganda, Ethiopia) or with acute water shortages such as the Sahel states (Mali, Burkina Faso, Niger, Chad), probably becoming a pole of famine and epidemics and a major source of emigration. Their main geopolitical goal (similar to the states of the Eurasian Heartland) will be to own commercial corridors to the coast. The result of this demographic explosion will create, either the largest 
land mass in civil and intra-state warfare, or in a more optimistic framework, the plan of an increasingly territorially united Africa will be launched, in which wetter areas and cities of on the coast with access to development will receive tens or hundreds of millions of immigrants from within the isolated continent, underdeveloped and hit by drought.

\section{REFERENCES}

Bessis, S. (2004). Occidentul și ceilalți (The West and the others), Editura Runa, București, (in Romanian). Carmody, P. (2013). The Rise of the BRICS in Africa: The Geopolitics of South-South Relations, Publisher : Zed Books, Londra, Marea Britanie.

Diaconescu, L. (2017). Global Competition Between North and South. Revista Română de Geografie Politică, 19(2), 103-115.

Diaconescu, L. (2018). Geopolitics of the Oceans: The Demographic Influence in the Separation of Powers. Revista Română de Geografie Politică, 20(2), 75-85.

Diaconescu, L., Nichitut, N., Lung, M.S. (2019). Colossi-Crumbs in the year 1900 - Colossi-Colossi in the year 2100. Transfer of demographic-economic predominance from Eurasia to Afroamerica. Revista Română de Geografie Politică, 21(2), 50-59.

Favari, S. (2014). Scacchiera africana. Confronto di strategie tra Cina e Stati Uniti nel continente nero, Editore Fuoco Edizioni, Roma, Italia (in Italian).

Ferrara, G. (2017). Geographical delocalization of italian firms in Africa. Revista Română de Geografie Politicā, 19(1), 24-29.

Gâștescu, P., Cioacă, A. (2013). Insulele Terrei (Earth Islands), Editura CD Press, București (in Romanian).

Guillermo, M.J. (2015). Geopolitica de África, Editorial Dunken, Buenos Aier, Argentina.

Herman, G.V., Grama, V. (2018). Geographical aspects of space-time evolution of independent states, Revista Românā de Geografie Politicā, 20(2), 49-56.

Hugon, P. (2015). Geopolitica de África, Escolar Editora, Lisabona, Portugalia.

Huntington, S.P. (2018). Ciocnirea civilizațiilor şi refacerea ordinii mondiale (The clash of civilizations and the restoration of world order), Litera Publishing House, București (in Romanian).

Kaplan, R.D. (2015). Răzbunarea geografiei. Ce ne spune harta despre conflictele viitoare și lupta impotriva destinului (Revenge of geography. What the map tells us about future conflicts and the fight against destiny), Litera Publishing House, București (in Romanian).

Lopes, H. (2006). African geopolitics: Africa, the constitutional state and development, UNESCO Publishing, Paris, Franța.

Maesto, R. (2019). La variabile africana. Riserve naturali ed equilibrio geopolitico del pianeta, Editore EGEA, Milano, Italia.

Marin, M., Marin, I. (2008). Medii şi regiuni geografice (Geographic environments and regions), Universitară Publishing House, București (in Romanian).

Marshall, T. (2019). Prizonierii geografiei. Zece hărți care ựi spun tot ce trebuie să ști despre politica globală (The prisoners of geography. Ten maps that tell you everything you need to know about global politics), Litera Publishing House, București (in Romanian).

Mazilu, M.E. (2008). To be or not to be afraid of globalizationin Journal?, Analele Universității din Craiova, Seria Geografie, 11, 87-91 (in Romanian).

Mâșu, Ș. (2014). Puterea economică în istoria lumii. De la Marele Rift la Marele Război din 1914 (Economic power in the history of the world. From the Great Rift to the Great War of 1914), Rao Publishing House, București (in Romanian).

Meinig, D. W. (1956). Heartland and rimland in Eurasian history. Western Political Quarterly, 9(3), 553-569.

Melinescu, N. (2018). Inapoi în Africa (Back to Africa), Editura Cetatea de Scaun, Târgoviște (in Romanian).

Neguț, S. (2011). Geografie umană (Human geography), Editura Academiei Române, București (in Romanian). Nguyen, E. (2017), Géopolitique de l'Afrique, Editeur Studyrama Eds, Paris, Franța (in French).

Roberts, P. (2009). Sfârşitul hranei (The end of food), Editura Litera Internațional, București (in Romanian).

Sawandji, J.J.A. (2018). Globalizzazione e conflitti. Un itinerario geopolitico sull'Africa subsahariana, Editore Aracne, Roma, Italia (in Italian).

Woddis, J. (1965). Calea Africii (The Way of Africa), Editura Politică, București (in Romanian).

***Worldometers, real time world statistics: www.worldometers.info, last accessed, June, 2020.

Submitted:

August 20, 2020
Revised:

December 22, 2020
Accepted and published online: January 05, 2021 